\title{
The Influence of Financial Indicators, Corporate Governance and Macroeconomic Variables on Financial Distress
}

\author{
Made Reina Candradewi \\ Henny Rahyuda \\ Universitas Udayana
}

\begin{abstract}
This study aims to analyzes the effect of financial indicators, corporate governance and macroeconomic variables on financial distress of manufacturing companies listed in Indonesian Stock Exchange (IDX) for the period 2016-2018. This research is expected to provide solutions and insight for the companies in tackling financial distress. This research employs quantitative approach. The sampling technique is purposive sampling method and the final sample is 136 companies. This research uses descriptive statistics and logistic regression analysis. The main findings of the research show that liquidity ratio has a negative and significant effect on financial distress, leverage ratio has a positive and significant effect on financial distress, activity ratio has a negative and significant effect on financial distress and the size of the board of directors has a negative and significant effect on financial distress. Companies must pay attention to financial performance and corporate governance to prevent financial distress.
\end{abstract}

Keywords: financial indicators, corporate governance, macroeconomic, financial distress

JEL classification: G2, G3, E4

\section{INTRODUCTION}

The economy of a country is greatly affected by the movement of the business world. A country can be stated to have a good economy, if there is an increase movement its business world. However, the country's economy is said to have worsened when there is downturn in the business world. This condition is shown if many companies experiencing financial difficulties and even bankruptcy. Moreover, the manufacturing industry has a significant role in the Indonesian economy. Based on data from the Indonesian Central Statistics Agency (Badan Pusat Statistik - BPS), the manufacturing industry provides a sizeable contribution to Indonesia's Gross Domestic Product (GDP). In 2017, the manufacturing industry contributed IDR 
2,103.07 trillion to the Indonesian economy, or around $21.22 \%$ of Indonesia's GDP.

The problem that occurs is that in 2018 there were 33 manufacturing industry companies on the Indonesian Stock Exchange (IDX) that had negative Earning Per Share (EPS). A company that has a negative EPS indicates that the company is experiencing financial distress or financial difficulties. This is very important to consider because financial distress is an early sign or signal of bankruptcy in the company. Financial distress and the risk of bankruptcy experienced by companies in the manufacturing industry will indirectly reduce the condition of Indonesian economy. Therefore, it requires an indepth analysis of what factors can influence financial distress that occurs in manufacturing industrial companies on the IDX.

Financial indicators, corporate governance and macroeconomic variables are important factors that can affect the possibility of financial distress in a company. Financial indicators reflect a company's financial performance which can be measured by liquidity, leverage and activity ratio. When a company has good financial performance, the possibility of financial distress will be lower. Previous research by Pulungan et al. (2017) stated that the company's liquidity level had a significant negative effect on financial distress. This finding is supported by Widhiari and Merkusiwati (2015). However, different results were found by Agustini and Wirawati (2019) who concluded that the liquidity ratio had no effect on financial distress. Pranowo et al. (2010) in their research emphasized that leverage has a significant effect on financial distress experienced by companies. The results of this study were supported by Agustini and Wirawati (2019) who came to a similar conclusion. However, research by Widhiari and Merkusiwati (2015) found different results that leverage is not able to influence the possibility of financial distress. Activity ratio, measured by total assets turnover, was found to have a significant effect on financial distress as stated in the previous research by Dewi and Dana (2017). Research by Agustini 
and Wirawati (2019) came to the same conclusion. However, it is different from the results of research by Kariani and Budiasih (2017) which found that the activity ratio has no effect on financial distress.

Corporate governance is a system in a company that regulates the relationship between shareholders, board of directors, board of commissioners, managers, employees and all stakeholders in the company. The implementation of good corporate governance could be employed as an action to prevent financial distress (Bredart, 2014). Important indicators of corporate governance that need to be considered are the proportion of independent commissioners, board size and managerial ownership. Empirical research by Salloum and Azoury (2013) found that board outsiders have a significant negative effect on financial distress. However, it is different from the results of research by Cinantya and Merkusiwati (2015) which found that the variable proportion of independent commissioners has no effect on financial difficulties. Previous research by Salloum and Azoury (2013) and Bredart (2014) found empirical evidence that board size has a negative and significant effect on financial distress. However, different results were obtained in empirical research by Cinantya and Merkusiwati (2015) which found that the size of the board of directors had no effect on financial distress. The research from Deviacita (2012) concluded that managerial ownership has a significant negative effect on financial distress. This result is contrary to research conducted by Cinantya and Merkusiwati (2015) which found evidence that managerial ownership has no effect on financial distress.

External factors that are important to be considered in influencing financial distress are macroeconomic variables that reflect the state of a country's economy, including inflation, exchange rates and interest rates. Research by Rachmawati et al. (2012) found that inflation and interest rates have a significant effect on financial distress. Meanwhile, research by Darmawan (2017) found the opposite result that inflation and interest rates have 
no effect on financial distress. Rohiman and Damayanti (2019) in their research found that exchange rates have a significant effect on financial distress. However, research by Darmawan (2017) and Rachmawati et al. (2012) found different results that the exchange rate had no effect on financial distress.

The difference results of previous empirical research have created a research gap for conducting in-depth analysis of how financial indicators, corporate governance and macroeconomic variables affect financial distress. There is hardly any research, that has analyzed the overall analysis by integrating these factors, including liquidity ratio, leverage ratio, activity ratio, proportion of independent commissioners, board size, managerial ownership, inflation, exchange rates and interest rates, which affect financial distress. The implementation of this research is expected to help companies in Indonesia to cope with financial distress, so that the companies can survive and contribute to the Indonesian economy.

\section{Hypothesis Formulation}

Financial distress can be experienced by every company, both small and large scale companies. Financial distress is a situation when a company cannot meet or face difficulties in paying off financial obligations to creditors (Khaliq et al, 2014). In addition, Platt and Platt (2002) define financial distress as a condition in which the company's financial is experiencing a decline, crisis or being unhealthy prior to bankruptcy or liquidation.

Financial indicators can be used as a basis for predicting financial distress (Jiming and Weiwei, 2011). Financial indicators reflect the company's financial performance which can be measured using financial ratio analysis including liquidity ratio, leverage ratio, profitability ratio, activity ratio and market ratio (Horne and Wachowicz, 2008; Al-Khatib and Al-Horani, 2012). In the analysis of factors that affect financial distress, the three most important financial indicators are used, which are the liquidity ratio, the leverage ratio and the activity ratio.

The liquidity ratio reflects the company's ability to meet its short-term needs by 
using the company's current assets (Horne and Wachowicz, 2008). Liquidity can be measured using the current ratio (CR) by dividing the company's current assets and current liabilities (Brigham and Houston, 2015). The low level of the company's liquidity ratio indicates the company's inability to meet its short-term needs. The high level of company liquidity reflects that the company can fulfill its short-term obligations and is able to finance operational activities. A company is said to be liquid, when it has sufficient cash. The high liquidity of a company indicates that the company has a good financial condition, so that the company could avoid financial distress from happening. Widhiari and Merkusiwati (2015) concluded that liquidity has a significant negative effect on financial distress. Pulungan et al. (2017) also found that liquidity has a significant effect on financial distress.

Hypothesis 1: Liquidity ratio has a negative and significant effect on financial distress

The leverage ratio shows how much the company uses loan funds to finance the assets owned by the company (Brigham and Houston, 2015). Leverage ratio can be measured using the debt to equity ratio (DER) by dividing the level of debt by the level of equity owned by the company. When a company has a high level of leverage, this means that the company has a high level of debt. Companies that have a high level of debt in their capital structure will experience an increase in interest costs that must be borne, which will cause financial distress (Hardwick and Adams, 1999). In addition, Pranowo et al. (2010) found that leverage has a significant effect on financial distress.

Hypothesis 2: Leverage ratio has a positive and significant effect on financial distress

Activity ratio is a financial ratio that measures the level of effectiveness of a company in using its assets. Activity ratio can be measured using total assets turnover (TAT) by dividing the level of sales by the company's total assets (Horne and Wachowicz, 2008). The high level of a company's TAT reflects that the company has a bigger sales volume. If the sales volume of the company is large, the profit 
generated by the company will increase. Increasing profit will certainly increase the company's wealth, so that the company will avoid financial distress. Research by Dewi and Dana (2017) found that the activity ratio as measured by TAT has a significant effect on financial distress. Similar research results were obtained in empirical research from Agustini and Wirawati (2019).

Hypothesis 3: Activity ratio has a negative and significant effect on financial distress

Corporate governance is a series of relationships between shareholders, the board of directors, the board of commissioners, management and other stakeholders (OECD, 2014). In other words, corporate governance is a system that regulates the relationship between shareholders, the board of directors, the board of commissioners, managers, creditors, government, employees and all stakeholders in the company. The function of corporate governance is to spur the efficient use of company resources where accountability is needed in managing these resources (Osuoha, 2013). In addition, the main objective of implementing corporate governance is to create added value for stakeholders. Indicators of corporate governance that need to be examined in relation to financial distress are the proportion of independent commissioners, size of the board of directors and managerial ownership.

The proportion of independent commissioners is the ratio between the number of members of independent commissioners and commissioners from within the company. When a company has a higher proportion of independent commissioners, the board of commissioners will be able to supervise and provide advice to management more effectively because independent commissioners work professionally (Debby et al, 2014). The greater the number of independent commissioners in a company, the smaller the potential for financial distress to occur because company management has more supervision from management. Research by Salloum and Azoury (2013) found empirical evidence that board outsiders 
have a significant negative effect on financial distress.

Hypothesis 4: The proportion of independent commissioners has a negative and significant effect on financial distress

Board size is an important factor in corporate governance. When a company has a small number of members of the board of directors, it will trigger agency problems because the company's management ability to manage its operations has decreased. The bigger size of the board of directors will reduce the possibility of financial difficulties (Emiraldi, 2007). Therefore, it can be observed that a larger size of the board of directors will keep the company away from the tendency of financial distress (Bredart, 2014). Research by Salloum and Azoury (2013) concluded that board size has a significant negative effect on financial distress.

Hypothesis 5: Board size has a negative and significant effect on financial distress

Managerial ownership is the proportion of ordinary shares owned by management, which can be measured from the percentage of ordinary shares owned by management who are actively involved in making company decisions. The theory of corporate governance by Jensen and Meckling (1976) states that managerial ownership is an important issue in corporate governance theory. This theory explains that the greater the proportion of managerial ownership in a company, the management will try to be more active in meeting the interests of shareholders who are also themselves. Managerial ownership will be able to reduce agency problems that arise in a company, so that the company will avoid financial distress problems. Research by Deviacita (2012) found evidence that managerial ownership has a significant negative effect on financial distress.

Hypothesis 6: Managerial ownership has a negative and significant effect on financial distress

Macroeconomic variables are external factors that can affect financial distress. Macroeconomic variables are factors that cover broad economic conditions such as inflation, interest rates and exchange 
rates. Inflation is a tendency to increase the price level in general and continuously (Friedman, 2007). When a country has a high inflation rate, this will push up raw material prices and increase operating costs. This situation will cause the selling price of the company's goods and cause a decrease in people's purchasing power. When this happens, the company's sales will decrease and the company's profits will decrease so that the tendency for financial distress to increase. Thus, continuous inflation will increase the possibility of companies experiencing financial distress (Munthe, 2008). Rachmawati et al. (2012) found that inflation has a significant effect on financial distress.

Hypothesis 7: Inflation has a positive and significant effect on financial distress

The exchange rate is the price of a domestic currency in a foreign currency. The exchange rate is an amount of money from a certain currency which can be exchanged for units of the currency of another country. The rupiah exchange rate will greatly affect the production companies that rely on imported raw materials. The weakening of the rupiah currency will increase the costs that must be borne by the company, namely an increase in production costs so that it has an impact on decreasing the company's profitability (Darminto, 2010). This condition will cause an increase in the tendency of financial distress in the company. Rohiman and Damayanti (2019) found that exchange rates have a significant effect on financial distress.

Hypothesis 8: Exchange rates have a negative and significant effect on financial distress

The interest rate is the amount of interest paid per unit of time which is referred to as a percentage of the amount borrowed. One must pay for the opportunity when borrowing money. Thus, the interest rate is the cost incurred when borrowing money which is measured as a percentage of the money borrowed (Samuelson and William, 2004). Case and Fair (2004) state that the interest rate is the annual interest payment on a loan expressed as a percentage of the loan. The amount is equal to the amount of interest received per year divided by the amount of the 
loan. The greater the interest expense commissioners, board size, managerial borne by the company, the more likely it ownership, inflation, exchange rates and is that a decline in profit will lead to interest rates on financial distress in financial distress (Brigham and Houston, manufacturing industrial companies 2015). Rachmawati et al. (2012) found that listed on the IDX in 2016-2018. interest rates have a significant effect on financial distress.

The dependent variable is the variable that is affected or that is the result of the Hypothesis 9: Interest rates have a positive and significant effect on financial distress

\section{RESEARCH METHODS}

This research uses quantitative methods. Research with quantitative methods will test the relationship between variables which are measured numerically and analyzed using statistical techniques (Saunders, 2016). This research is conducted to determine the effect of independent variable in the research model (Creswell, 2014). The dependent variable in this study is financial distress. Independent variables are variables that affect or cause changes in the dependent variable in the research model (Creswell, 2014). The independent variables in this research are liquidity, leverage, activity ratio, proportion of independent commissioners, board size, managerial ownership, inflation, exchange rates and interest rates. The research design in this liquidity, leverage, activity ratio, study can be seen in Figure 1.

proportion of independent

Figure 1: Research Design 


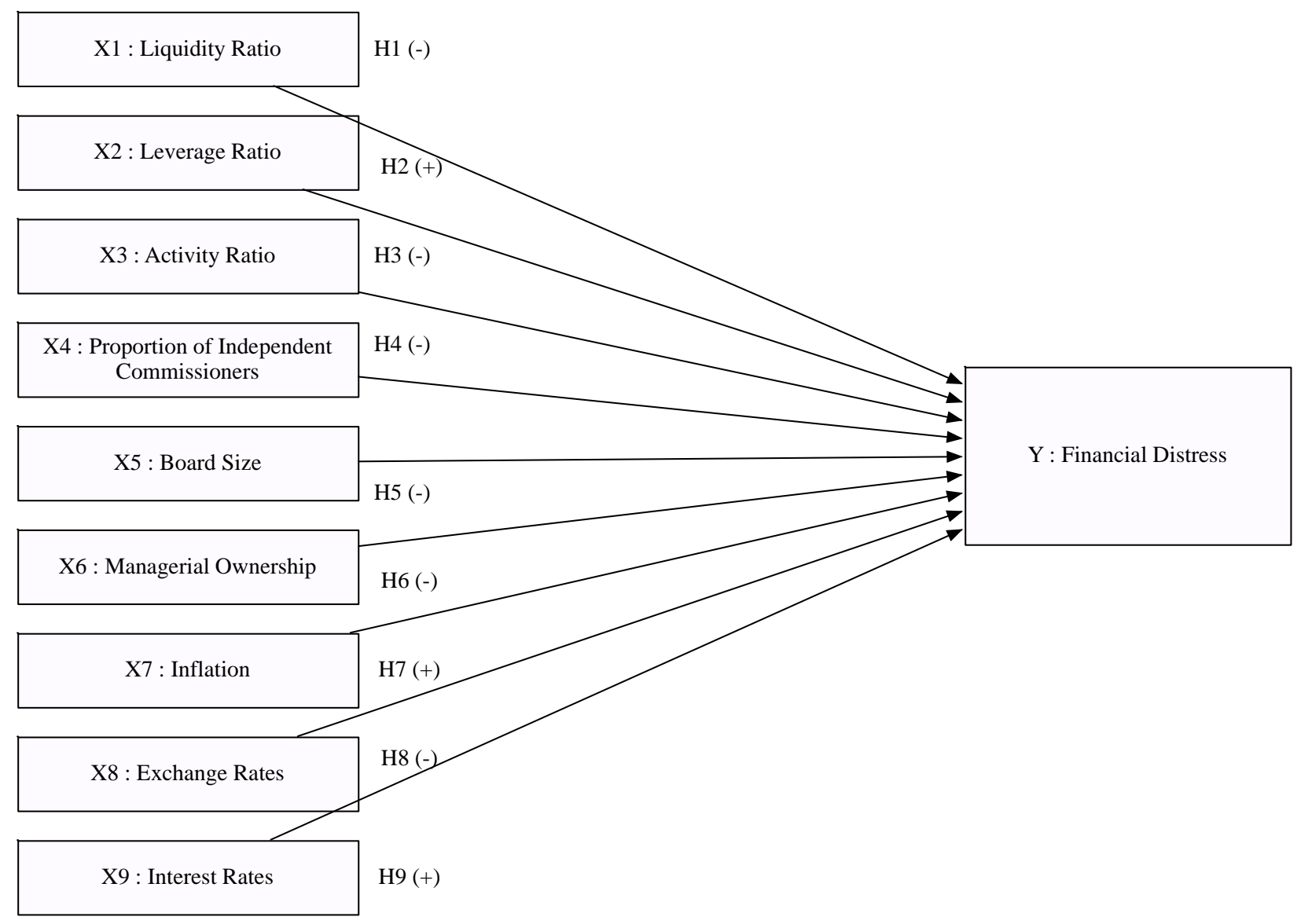

This research was conducted in proportion of independent Indonesia, namely manufacturing commissioners, board size, managerial companies listed on the IDX for the ownership, and financial distress can be period 2016 to 2018. This location was chosen because the IDX is the only stock exchange in Indonesia and all companies listed in Indonesia through the Indonesia Stock Exchange.

All data in this study are quantitative data. In addition, this study uses secondary data, where all the data such as liquidity, leverage, activity ratio, obtained from the annual financial reports of each company published on the IDX website and data on inflation, exchange rates and interest rates can be obtained through BPS and the Bank Indonesia website.

This study aims to determine the effect of financial indicators, corporate governance and macroeconomic 
variables on financial distress in manufacturing industrial companies listed on the IDX. Thus, the population in this study were all companies listed in the manufacturing industry on the IDX in 2018. The sampling technique in this study was the purposive sampling method. Purposive sampling method is a sampling technique based on the criteria determined by the researcher. The sampling criteria used in this study were manufacturing companies that were always listed on the IDX for the period 2016 to 2018. There were 136 manufacturing companies that met the sample criteria.

The following is the operational definition of all variables used in this study:

1. Liquidity Ratio $\left(X_{1}\right)$ is measured using the current ratio (CR), which is calculated by dividing current assets with current liabilities in manufacturing companies on the IDX from 2016 to 2018. The scale of this data is the ratio and the unit is a percentage.
2. Leverage Ratio $\left(X_{2}\right)$ is measured using the debt to equity ratio (DER), which is by dividing debt with equity in manufacturing companies on the IDX from 2016 to 2018. The scale of this data is the ratio and the unit is times.

3. Activity Ratio $\left(X_{3}\right)$ is measured using the ratio of total assets turnover (TAT) by dividing the level of sales by the total assets of manufacturing companies on the IDX from 2016 to 2018. The scale of this data is the ratio and the unit is times.

4. Proportion of independent commissioners $\left(\mathrm{X}_{4}\right)$ is the proportion of the number of members of independent commissioners compared to commissioners from within the company. This proportion is measured by dividing the number of company independent commissioners and the total number of commissioners in manufacturing companies on the IDX from 2016 to 2018. This data 
scale is ratio data and the unit is times.

5. Board size $\left(X_{5}\right)$ is the total number of members of the board of directors in manufacturing companies on the IDX from 2016 to 2018. The scale of this data is nominal and the units are people.

6. Managerial ownership $\left(X_{6}\right)$ is the proportion of the number of shares owned by the board of directors and commissioners in the company compared to the total number of shares in the company. This proportion is measured by dividing the number of shares owned by the board of directors and commissioners with the total number of shares in manufacturing companies on the IDX from 2016 to 2018. This data scale is ratio data and the unit is a percentage.

7. Inflation $\left(X_{7}\right)$, measured by the average annual inflation obtained from the publication of Bank Indonesia for the period 2016 2018.
8. Exchange rates $\left(X_{8}\right)$, measured by calculating the middle value between the rupiah selling and buying rates published by Bank Indonesia for the period 2016 2018.

9. Interest rates $\left(X_{9}\right)$, measured by the average interest rate determined by Bank Indonesia each year, obtained from Bank Indonesia publications for the period 2016 - 2018.

10. Financial Distress $(Y)$ is a financial difficulty in manufacturing companies on the IDX in 2016 - 2018, which is measured by the companies that have negative EPS in one reporting period. This variabel is a dummy variable. If a company experiencing financial distress is given a score of 1 , and a company that does not experience financial distress is given a score of 0 .

The data analysis technique used in this research is descriptive analysis and regression analysis using the SPSS program. The first data analysis conducted in this study was descriptive 
statistics. Descriptive statistics is a data analysis method used to characterize the data that has been collected (Sugiyono, 2017). Descriptive statistics in this study will calculate the average, standard deviation, and percentage of the sample data for all variables with the ratio data.

The second data analysis conducted in this study is inferential analysis. Inferential analysis is used to test the hypotheses formulated in this study. The inferential analysis technique used in this research is logistic regression analysis through the Statistical Package for Social Science (SPSS) program. The test is carried out using logistic regression analysis because in this study, the dependent variable is a dummy variable and has more than one independent variable.

\section{RESULT AND DISCUSSION}

Descriptive statistical analysis was conducted to provide an overview or description of the research variables consisting of financial distress (Y), liquidity ratio $(\mathrm{X} 1)$, leverage ratio $(\mathrm{X} 2)$, activity ratio $(\mathrm{X} 3)$, proportion of independent commissioners (X4), board size (X5), managerial ownership (X6), inflation (X7), exchange rates (X8) and interest rates (X9) through the average (mean) value, maximum value, minimum value and standard deviation.

Table 1: Descriptive Statistics of Research Variables

\begin{tabular}{llrrrr}
\hline & N & Minimum & Maximum & \multicolumn{1}{c}{ Mean } & Standard Deviation \\
\hline $\mathrm{Y}$ & 408 & .00 & 1.00 & .2034 & .40304 \\
$\mathrm{X}_{1}$ & 408 & 10.64 & 792.50 & 212.9656 & 162.61837 \\
$\mathrm{X}_{2}$ & 408 & .08 & 17.91 & 1.4514 & 2.03356 \\
$\mathrm{X}_{3}$ & 408 & .01 & 4.80 & .8837 & .56472 \\
$\mathrm{X}_{4}$ & 408 & .00 & .75 & .3779 & .12249 \\
$\mathrm{X}_{5}$ & 408 & 2.00 & 16.00 & 4.9902 & 2.22227 \\
$\mathrm{X}_{6}$ & 408 & .00 & 89.44 & 5.8490 & 14.06799 \\
$\mathrm{X}_{7}$ & 408 & 3.20 & 3.81 & 3.5133 & .24962 \\
$\mathrm{X}_{8}$ & 408 & 13329.00 & 14268.00 & 13664.3333 & 428.25741 \\
$\mathrm{X}_{9}$ & 408 & 4.60 & 5.30 & 5.0000 & .29475 \\
\hline
\end{tabular}

Source: secondary data processed 
Table 2: Hosmer and Lemeshow Test Results

\begin{tabular}{cccc}
\hline Step & Chi-square & $d f$ & Sig. \\
\hline 1 & 2.413 & 8 & .966 \\
\hline
\end{tabular}

Source: secondary data processed

Table 3: Comparison of the Initial -2LL Value and the Final -2LL Value

\begin{tabular}{ll}
\hline -2LL initial (Block Number $=0)$ & 412.180 \\
\hline -2LL final (Block Number $=1$ ) & 327.446 \\
\hline
\end{tabular}

Source: secondary data processed

Table 4: Results of the Determination Coefficient Test

\begin{tabular}{cccc}
\hline Step & $\mathbf{- 2}$ Log likelihood & $\begin{array}{c}\text { Cox \& Snell R } \\
\text { Square }\end{array}$ & $\begin{array}{c}\text { Nagelkerke } \mathbf{R} \\
\text { Square }\end{array}$ \\
\hline 1 & 327.425 & .188 & .295 \\
\hline
\end{tabular}

Source: secondary data processed

Table 5: Classification Matrix

\begin{tabular}{|c|c|c|c|c|}
\hline & \multicolumn{3}{|c|}{ Predicted } \\
\hline & & $\mathrm{Y}$ & & \\
\hline & & $\begin{array}{l}\text { No Financial } \\
\text { Distress }\end{array}$ & $\begin{array}{c}\text { Financial } \\
\text { Distress }\end{array}$ & $\begin{array}{c}\text { Percentage } \\
\text { Correct }\end{array}$ \\
\hline \multirow[t]{3}{*}{ Step 1} & No Financial Distress & 316 & 9 & 97.2 \\
\hline & Financial Distress & 59 & 24 & 28.9 \\
\hline & Overall Percentage & & & 83.3 \\
\hline
\end{tabular}

Source: secondary data processed

Table 6: Logistic Regression Analysis Results

\begin{tabular}{cccccccc}
\hline & & B & S.E. & Wald & df & Sig. & Exp(B) \\
\hline Step 1 & X1 & -.006 & .002 & 13.217 & 1 & .000 & .994 \\
& X2 & .173 & .076 & 5.196 & 1 & .023 & 1.189 \\
& X3 & -1.412 & .351 & 16.209 & 1 & .000 & .244 \\
X4 & -1.586 & 1.110 & 2.041 & 1 & .153 & .205 \\
X5 & -.224 & .076 & 8.765 & 1 & .003 & .799 \\
X6 & .008 & .009 & .718 & 1 & .397 & 1.008 \\
X7 & .568 & 2.891 & .039 & 1 & .844 & 1.765 \\
X8 & .000 & .001 & .007 & 1 & .932 & 1.000 \\
X9 & -.397 & 1.221 & .106 & 1 & .745 & .672 \\
\hline
\end{tabular}


Source: secondary data processed

Table 1 shows that the amount of data used in this study amounted to 408 data points obtained from a total sample of 136 companies during the 2016-2018 period. The financial distress variable $(\mathrm{Y})$ is a dummy variable. The value of 1 is given to manufacturing companies listed on the IDX for the 2016-2018 period that experienced financial distress, while the value of 0 is for manufacturing companies listed on the IDX for the 2016-2018 period that did not experience financial distress. Overall, the average value of the financial distress variable is 0.2034 with a standard deviation of 0.40304 .

The variable liquidity ratio (X1) has a minimum value of $10.64 \%$, namely the Asia Pacific Fibers Tbk company in 2016. and a maximum value of $792.50 \%$, namely the Multi Prima Sejahtera Tbk company in 2018. These results also show that the average value of the liquidity ratio is 212.96 and the standard deviation is 162.61 .
The leverage ratio variable $(\mathrm{X} 2)$ has a minimum value of 0.08 , namely in the Sido Muncul Tbk Herbal and Pharmaceutical Industry company in 2016. The maximum value is 17.91 , namely the company Apac Citra Centertex Tbk in 2018. These results also show that the average value of leverage ratio is 1.45 and the standard deviation is 2.03 .

The activity ratio variable (X3) has a minimum value of 0.01 , namely the Inti Keramik Alam Asri Industri Tbk company in 2018 and a maximum value of 4.80, namely the Beton Jaya Manunggal Tbk company in 2017. These results also indicate that the average value of activity ratio is 0.88 and the standard deviation is 0.56 .

The variable proportion of independent commissioners (X4) has a minimum value of 0 , namely the 2016 Waskita Beton Precast Tbk company and a maximum value of 0.75 , namely the Bentoel International Investama Tbk 
company in 2016. These results also show that the average value of proportion of independent commissioner is 0.37 and the standard deviation is 0.12 .

The variable of the size of the board of directors (X5) has a minimum value of 2 , namely in the company Inti Keramik Alam Asri Industri Tbk in 2016 and a maximum value of 16 is the company Mandom Indonesia Tbk in 2016. These results also show that the average value of the board size is 4.99 and the standard deviation is 2.22 .

The managerial ownership variable (X6) has a minimum value of 0 , which is a total of 225 data points and the maximum value of 89.44 , namely the Beton Jaya Manunggal Tbk company in 2017. These results also show that the average value of the managerial ownership variable is 5.84 and the standard deviation is 14.06 .

The inflation variable (X7) has a minimum value of 3.20, that is in 2018 . Then the maximum value is 3.81 , that is in 2017. The results also show that the average value of the inflation variable is 3.51 and the standard deviation is 0,24 . The rupiah exchange rate variable $(\mathrm{X} 8)$ has a minimum value of 13,329 , that is in 2016. Then the maximum value is 14,268 , that is in 2018. These results also show that the average value of the rupiah exchange rate variable is 13,664 and the standard deviation is 428.25 .

The interest rate variable (X9) has a minimum value of 4.60, that is in 2017 . Then the maximum value is 5.30 , that is in 2016. The results also show that the average value of the interest rate variable is 5 and the standard deviation is 0,29 .

The feasibility of the regression model was assessed using the Hosmer and Lemeshow test. The test results can be seen in Table 2. Table 2 shows that the value of the Chi-square is 2.413 with a significance value of 0.966 . Based on the test results, the significance value is greater than 0.05 , so it can be concluded that the model is able to predict the observation value or the model can be accepted because it fits the actual data. 
Testing to assess the overall model can be done by comparing the value of -2 Log Likelihood (LL) at block number $=0$ with the value -2 Log Likelihood (LL) at block number $=1$. The test results can be seen in Table 3. In Table 3 it can be observed that the initial -2LL value is 412.180 and the final -2LL value has decreased to 327.446. The decrease in the $-2 \mathrm{LL}$ value indicates that the regression model being tested is good, meaning that the hypothesized model is fit with the data.

The coefficient of determination can be assessed from the value of the Nagelkerke R Square. The test results are presented in Table 4 . Table 4 shows that the Nagelkerke R Square value is 0.295. This value means that the variability of the dependent variable which can be explained by the independent variable is $29.5 \%$, while the remaining $70.5 \%$ is explained by other variables outside the research model or which are not included in this study.

The classification matrix shows the predictive power of the regression model to calculate the likelihood of financial distress. The test results are presented in Table 5. Based on the results of the classification matrix test in Table 5, the predictive power of the regression model to predict the possibility that the company will not experience financial distress is $97.2 \%$. This value shows that from 425 total observations that do not experience financial distress, there are 316 total observations that are predicted not to experience financial distress, while 9 total observations are predicted to experience financial distress. The prediction strength of the possibility that the company will experience financial distress is $28.9 \%$. This value indicates that out of 83 total observations that experience financial distress, 59 total observations are predicted not to experience financial distress, while 24 total observations are predicted to experience financial distress.

Logistic regression analysis using the SPSS program was carried out in this study to analyze how the effect of liquidity ratio, leverage ratio, activity 
ratio, proportion of independent commissioners, board size, managerial ownership, inflation, exchange rates and interest rates on financial distress in manufacturing companies on the IDX for the period 2016 - 2018. The results of logistic regression analysis for testing the relationship between variables in this study can be seen in Table 6 .

The results of the analysis show that the liquidity ratio variable has a negative regression coefficient of -0.006 with $p<0.05$. The negative direction indicates that the higher the level of a company's liquidity ratio, the company's financial distress tends to decrease. The results of this study support the first hypothesis (H1) which states that the liquidity ratio has a significant negative effect on financial distress. This means that an increase or decrease in the liquidity ratio influences the increase or decrease in financial distress in manufacturing companies listed on the IDX in 20162018.

One of the measurements of financial performance is seen through the liquidity ratio. Liquidity ratio reflects the company's ability to meet its shortterm needs by using current assets owned by the company. The low level of the company's liquidity ratio shows the company's inability to meet its shortterm needs. The high level of company liquidity reflects that the company can fulfill its short-term obligations and is able to finance operational activities. The high liquidity of a company indicates that the company has a good financial condition, so that the company could avoid financial distress from happening. The results of this study theoretically support that the liquidity ratio and financial distress have a negative relationship. These findings also support the results of research conducted by Widhiari and Merkusiwati (2015) and Pulungan et al. (2017)

The results of the analysis show that the leverage ratio variable has a positive regression coefficient of 0.173 with $p<0.05$. The positive direction shows that the higher the level of a company's leverage ratio, the company's financial distress tends to increase. The results of 
this study support the second hypothesis (H2) which states that the leverage ratio has a significant positive effect on financial distress. This means that an increase or decrease in the leverage ratio influences the increase or decrease in financial distress in manufacturing companies listed on the IDX in 2016-2018.

\section{Another important financial} performance is leverage. Leverage ratio shows how much the company uses loan funds to finance assets owned by the company. Companies that have a high level of leverage reflect that the company has a high level of debt. The large proportion of the use of debt in the company will cause an increase in interest costs that must be borne so that it will cause financial distress to the company. The results of this study theoretically support that leverage and financial distress have a positive relationship. The findings in this study also support the results of research conducted by Pranowo et al. (2010).

The analysis result shows that the activity ratio variable has a negative regression coefficient of -1.412 with $p<0.05$. The negative direction shows that the higher the level of a company's activity ratio, the company's financial distress tends to decrease. The results of this study support the third hypothesis (H3) which states that the activity ratio has a significant negative effect on financial distress. This means that an increase or decrease in activity ratio influences the increase or decrease in financial distress in manufacturing companies listed on the IDX in 20162018.

Activity ratio is a financial ratio that measures the level of effectiveness of a company in using its assets. Activity ratio can be measured using total assets turnover (TAT) by dividing the level of sales by the company's total assets. When a company has a high TAT level, the company has a bigger sales volume. The large sales volume of the company will increase the profit generated by the company. Increasing profit will certainly increase the company's wealth, so that the company could avoid financial distress. The results of this 
study theoretically support that the activity ratio and financial distress have a negative relationship. The findings in this study also support the results of research conducted by Dewi and Dana (2017).

The analysis result shows that the variable proportion of independent commissioners has a negative regression coefficient of -1.586 with $p>0.05$. This shows that the proportion of independent commissioners does not have a significant effect on financial distress in manufacturing companies listed on the IDX in 2016-2018. This result does not support the fourth hypothesis (H4) which states that the proportion of independent commissioners has a significant negative effect on financial distress. The proportion of independent commissioners was found to have a negative, but not significant, effect on financial distress.

The implementation of good corporate governance can be seen from the proportion of independent commissioners in a company. The board of commissioners of a company will be able to supervise better and provide advice to management more effectively, when it has a higher proportion of independent commissioners. Therefore, the higher the proportion of independent commissioners, the smaller the tendency for financial distress to occur in a company. However, in this study, the results show that the proportion of independent commissioners has not been able to have a real effect on financial distress. This is most likely due to other factors that have a greater influence on financial distress, such as liquidity, leverage, activity ratio and board size. The results of this study do not support the results of previous studies by Salloum and Azoury (2013).

The analysis results show that the variable board size has a negative regression coefficient of -0.224 with $p<0.05$. The negative direction shows that the higher the size of the board of directors of a company, the company's financial distress tends to decrease. The results of this study support the fifth 
hypothesis (H5) which states that board size has a significant negative effect on financial distress. This means that an increase or decrease in the board size influences the increase or decrease in financial distress in manufacturing companies listed on the IDX in 20162018.

The board of directors is part of the company who authorize and fully responsible for managing the company for the benefit of the company. The size of the board of directors that is larger in a company, will increase the ability of company management in managing its operations. In addition, the size of the board of directors in a company also plays role in reducing agency problems. Therefore, the size of the board of directors has an important effect in reducing the possibility of financial difficulties. The results of this study theoretically support that board size and financial distress have a negative relationship. The findings in this study also support the results of research conducted by Salloum and Azoury (2013).
The analysis results show that the managerial ownership variable has a positive regression coefficient of 0.008 with $p>0.05$. This shows that managerial ownership does not significantly affect financial distress in manufacturing companies listed on the IDX in 20162018. This result does not support the sixth hypothesis (H6) which states that managerial ownership has a significant negative effect on financial distress. Managerial ownership was found to have a positive, but insignificant, effect on financial distress.

Theoretically and based on the results of previous research, a hypothesis has been formulated in this study that managerial ownership has a negative and significant effect on financial distress. However, the results of research conducted on manufacturing companies listed on the IDX in 2016 2018 show that the higher the level of managerial ownership of the company, the more likely the company will experience financial distress. This is most likely because most companies do not implement managerial ownership 
programs. From 136 companies, only 61 companies implemented managerial ownership programs. The results of this study found a positive and insignificant relationship between managerial ownership and financial distress. The results of this study do not support the results of previous studies by Deviacita (2012).

The analysis result shows that the inflation variable has a positive regression coefficient of 0.568 with $p>0.05$. This shows that inflation does not have a significant effect on financial distress in manufacturing companies listed on the IDX in 2016-2018. These results do not support the seventh hypothesis (H7) which states that inflation has a significant positive effect on financial distress. Inflation was found to have a positive, but insignificant, effect on financial distress.

A positive sign on the inflation regression coefficient indicates that when the state of inflation increases, the tendency for financial distress will increase. The higher the level of inflation in a country, the higher the selling price of goods and the company's sales level will decrease. This condition will cause company profits to decrease and the tendency for financial distress to be even greater. However, the insignificant results in this study do not support previous research by Munthe (2008) which proves that inflation is an important factor affecting financial distress. This may occur because inflation is not a strong driving factor in influencing the occurrence of financial distress in manufacturing companies on the IDX.

The analysis result shows that the exchange rate variable has a positive regression coefficient of 0.000 with $p>0.05$. This shows that the exchange rate does not significantly influence financial distress in manufacturing companies listed on the IDX in 20162018. This result does not support the eighth hypothesis (H8) which states that exchange rates have a significant positive effect on financial distress. Exchange rates were found to have a positive, but insignificant, effect on financial distress. 
The exchange rate is the price of the domestic currency in foreign currencies. The exchange rate is very important for companies whose production relies on imported raw materials. The weakening of the rupiah exchange rate will increase the costs that must be borne by companies. This will increase the possibility of financial distress in the company. However, this study found that the exchange rate had a positive, but insignificant, effect on financial distress. The results of this study contradict research by Darminto (2010).

This is probably due to other factors that have a greater influence on financial distress, such as financial indicators and corporate governance which are internal factors.

The analysis result shows that the interest rate variable has a negative regression coefficient of -0.397 with $p>0.05$. This shows that interest rates do not have a significant effect on financial distress in manufacturing companies listed on the IDX in 2016-2018. This result does not support the third hypothesis (H9) which states that interest rates have a significant positive effect on financial distress. Interest rates were found to have a negative, but insignificant, effect on financial distress.

The interest rate is simply the cost incurred when borrowing money which is measured in percentage of the money borrowed. The higher the interest rate, the greater the interest expense borne by the company and increases the likelihood of financial distress. However, this study found that interest rates have a negative and insignificant effect on financial distress. This may occur because an increase in interest rates will not necessarily increase financial distress if the company has a good leverage ratio. In addition, interest rates in this study do not have a major effect on financial distress in manufacturing companies on the IDX.

\section{CONCLUSION}

Several conclusions can be drawn from the results of data analysis and discussion. First, this study finds that the factors that most influence financial distress in manufacturing industrial companies listed on the Indonesia Stock 
Exchange (BEI) in 2016-2018 are liquidity, leverage, activity ratio and board size. While the other six factors, which are the proportion of independent commissioners, managerial ownership, inflation, exchange rates and interest rates do not have a significant effect on financial distress. Liquidity ratio has a negative and significant effect on financial distress with a significance level of $1 \%$. Leverage ratio has a positive and significant effect on financial distress with a significance level of $5 \%$. Activity ratio has a negative and significant effect on financial distress with a significance level of $1 \%$. The board size has a negative and significant effect on financial distress with a significance level of $1 \%$.

The results of the study provide advice to manufacturing industrial companies on the IDX that when the company has a high level of liquidity and activity ratio, the company could avoid financial distress from happening. It is important for companies to pay attention to the level of leverage, because a higher level of leverage will tend to increase the financial distress in the company. In addition, it is also important for companies to consider the board size, because increasing the size of the board of directors in the company is proven to be able to prevent financial distress. In formulating company policies and strategies, it is very important for company management to pay attention about the steps in improving financial performance and improving corporate governance so that the possibility of financial distress can be minimized. For the future research, it is important to pay attention to other internal factors such as market ratios, growth, company size and other external factors such as commodity prices, taxes and government policies in influencing financial distress which have not been examined in this study.

\section{REFERENCE}

Agustini, N.W. dan Wirawati, N.G.P. 2019. Pengaruh Rasio Keuangan pada Financial Distress Perusahaan Ritel yang Terdaftar di Bursa Efek Indonesia (BEI). EJurnal Akuntansi Universitas Udayana. Vol. 26 (1), pp. 251-280. 
Al-Khatib, H. B., dan Al-Horani, A. 2012. Predicting Financial Distress of Public Companies Listed in Amman Stock Exchange. European Scientific Journal. Vol. 8 (15), pp.437-449.

Altman, E. I. 1968. Financial Ratios, Discriminant Analysis and The Prediction of Corporate Bankruptcy. Journal of Finance. Vol. 23 (4), pp.589-609.

Bredart, X. 2014. Financial Distress and Corporate Governance: The Impact of Board Configuration. International Business Research, Vol. 7 (3), pp.72-80.

Brigham, E.F., dan Houston, J.F. 2015. Fundamentals of Financial Management. $8^{\text {th }} \quad$ Edition Concise. USA: Cengage Learning.

Case, K.E. dan Fair, R.C. 2004. Prinsip Prinsip Ekonomi Makro. Edisi Kelima. Alih bahasa oleh Bambang Sarwiji. Jakarta: PT. Indeks.

Cinantya, I.G.A.A.P., dan Merkusiwati, N.K.L.A. 2015. Pengaruh Corporate Governance, Financial Indicators dan Ukuran Perusahaan pada Financial Distress. E-Jurnal Akuntansi Universitas Udayana. Vol. 10 (3), pp. 897-915.

Creswell, J.W. 2014. Research Design, Qualitative, Quantitativem and
Mixed Methods Approaches. USA: Sage Publications, Inc.

Darmawan, S. 2017. Analisis Pengaruh Corporate Governance, Variabel Ekonomi Makro Terhadap Financial Distress dengan Variabel Kontrol Ukuran Perusahaan dan Jenis Kepemilikan. Jurnal Bisnis dan Ekonomi. Vol. 7 (1), Juni 2017, pp.100-122.

Darminto. 2010. Pengaruh Faktor Eksternal dan Berbagai Keputusan Keuangan Terhadap Nilai Perusahaan. Jurnal Aplikasi Manajemen.Vol. 8 (1), pp.138150.

Debby, J.F., Mukhtaruddin, Yuniarti, E., Saputra, D. dan Abukosim. 2014. Good Corporate Governance, Company's Characteristics and Firm's Value: Empirical Study of Listed Banking on Indonesian Stock Exchange. GSTF Journal on Business Review (GBR), Vol.3(4), pp.81-88.

Deviacita, A.W. 2012. Analisis Pengaruh Mekanisme Corporate Governance Terhadap Financial Distress. Diponegoro Journal of Accounting. Vol.1 (1), pp.1-15

Dewi, N.K.U.G. dan Dana, M. 2017. Variabel Penentu Financial Distress Pada Perusahaan Manufaktur di Bursa Efek Indonesia. E-Jurnal Manajemen Unud. Vol. 6 (11), pp.5834-5858. 
Emiraldi, N.D.P. 2007. Analisis Pengaruh Praktek Tata Kelola Perusahaan (Corporate governance) Terhadap Kesulitan Keuangan Perusahaan (Financial distress): Suatu Kajian Empiris. Jurnal Bisnis dan Akuntansi. Vol. 9 (1), pp. 84-108.

Friedman, M. 2007. Ekonomi Uang, Perbankan, Pasar Keuangan 2. Salemba Empat : Jakarta

Hardwick, P., Adams, M. 1999. The Determinants of Financial Derivatives Use in the United Kingdom Life Insurance Industry. Abacus. Vol. 35 (2), pp.163-184.

Horne, J.C.V., Wachowicz Jr., J.M. 2008. Fundamentals of Financial Management. $13^{\text {th }}$ Edition. England: Pearson Education Limited.

Jensen, M.C., Meckling, W.H. 1976. Theory of the Firm: Managerial Behavior, Agency Costs and Ownership Structure. Journal of Financial Economics, Vol.3 (October 1976), pp.305-360.

Jiming, L., dan Weiwei, D. 2011. An Empirical Study on the Corporate Financial Distress Prediction Based on Logistic Model: Evidence from China's Manufacturing Industry. International Journal of Digital Content Technology and its
Applications. Vol. 5 (6), pp.368379.

Kariani, N.P.K., dan Budiasih, I.G.A.N. 2017. Firm Size sebagai Pemoderasi Pengaruh Likuiditas, Leverage, dan Operating Capacity pada Financial Distress. E-Jurnal Akuntansi Universitas Udayana. Vol. 20 (3), pp.2187-2216.

Khaliq, A., Altarturi, B. H., Thaker, H. M., Harun, M. Y., \& Nahar, N. 2014. Identifying Financial Distress Firms: A Case Study of Malaysia's Government Linked Companies (GLC). International Journal of Economics, Finance and Management. Vol.3 (3), pp.141150.

Li, J. 2012. Prediction of Corporate Bankruptcy from 2008 Through 2011. Journal of Accounting and Finance. Vol. 12(1), pp.31-41.

Munthe, K. 2008. Pengaruh Struktur Kepemilikan, Makroekonomi, dan Kinerja Perusahaan Terhadap Kesulitan Keuangan Perusahaan. Media Unika Tahun 20, No. 73, Edisi Ke-4.

Platt, H., \& Platt, M. B. 2002. Development of a class of stable predictive variable: the case of bankruptcy predictions. Journal of Business Finance and Accounting. Vol. 17, pp. 31-51.

Pranowo, K., Achsani, N.A., Manurung, A.H., dan Nuryartono, N. 2010. 
The Influence of Financial Indicators, Corporate Governance and ....Made Reina Candradewi, Henny Rahyuda

\begin{abstract}
Determinant of Corporate Financial Distress in an Emerging Market Economy: Empirical Evidence from the Indonesian Stock Exchange 2004-2008. International Research Journal of Finance and Economics. Issue 52, pp.81-90.
\end{abstract}

Pulungan, K.P.A. et al. 2017. Pengaruh Likuiditas dan Leverage Terhadap Financial Distress pada Perusahaan Sub Sektor Keramik, Porselen dan Kaca yang Terdaftar di Bursa Efek Indonesia. Jurnal Financial. Vol. 3 (2), pp.1-9.

Rachmawati, R. et al. 2012. Analisis Variabel Mikro dan Makro terhadap Kesulitan Keuangan pada Perusahaan Tekstil dan Produk Tekstil yang terdaftar di Bursa Efek Indonesia. Jurnal Universitas Brawijaya.

Rohiman, S.F., dan Damayanti, C.R. 2019. Pengaruh Inflasi, Nilai Tukar dan Suku Bunga Terhadap Financial Distress (Studi Pada Semua Perusahaan yang Terdaftar di Bursa Efek Indonesia Periode 2013-2017). Jurnal Administrasi Bisnis (JAB). Vol. 72 (2), pp.186-195.

OECD. 2014. Risk Management and Corporate Governance. Corporate Governance. OECD Publishing.

Osuoha J. 2013. Financial engineering, corporate governance and
Nigeria economic development. Journal of Financial Risk Management, Vol. 2(4), pp. 61-66. Scientific Research Publishers, (SCIRP) United States of America.

Salloum, C.C. dan Azoury, N.M. 2013. Board of directors' effects on financial distress evidence of family owned businesses in Lebanon. International Entrepreneurship and Management Journal. Vol 9 (1), pp.59-75

Samuelson, P.A. dan William D.N. 2004. Ilmu Makroekonomi. Edisi Ketujuhbelas. Alih bahasa oleh Theresa Tanoto. Jakarta: PT. Media Global Edukasi.

Saunders, M., Lewis, F., Thornhil, A. 2016. Research Methods for Business Students, Italy: Pearson Education

Shahwan, T.M. 2015. The Effects of Corporate Governance on Financial Performance and Financial Distress: Evidence from Egypt. Corporate Governance International Journal of Business in Society. Vol. 15 (5), pp.641-662.

Sugiyono. 2017. Metode Penelitian Kuantitatif, Kualitatif dan RED. Bandung : Alfabeta, CV.

Widhiari, N.L.M.A. dan Merkusiwati, N.K.L.A. 2015. Pengaruh Rasio Likuiditas, Leverage, Operating Capacity, dan Sales Growth 
Terhadap Financial Distress. E-

Jurnal Akuntasi Universitas

Udayana. Vol.11 (2), pp.456-469.

www.bi.go.id

www.bps.go.id

www.idx.co.id 